\title{
Design and Construction of Automatic Portable Disinfectant Button to Prevent the Spread of The Covid-19 Virus
}

\author{
Akbar Sujiwa \\ Electrical Engineering \\ University of PGRI Adi Buana \\ Surabaya, Indonesia \\ akbarsujiwa@unipasby.ac.id
}

\author{
Irwan Puji Raharjo \\ Electrical Engineering \\ University of PGRI Adi Buana \\ Surabaya, Indonesia \\ irwanpuji46@gmail.com
}

\begin{abstract}
The Covid-19 virus is currently rampant in the world, especially in Indonesia, the spread of the Covid-19 virus is getting faster and wider. Even the spike in cases was unpredictable. Since entering Indonesia last March. In an effort to prevent it, almost every area carries out a body temperature test and sprays disinfectants on people who enter the area. This study aims to produce an automatic disinfectant sprayer and test its effectiveness. The method used is the data collection analysis method by testing the product. This tool uses ultrasonic sensors as object detectors, MLX 90614 sensors as temperature readers and Arduino Uno R3 as controllers. The output uses a Relay module that is connected to a Water Pump that sprays disinfectant liquid through a spray mist. This tool is effective in its manufacture and is able to detect objects in the area of the disinfectant booth. The results of the study found that the level of accuracy of the MLX 90614 sensor which was calibrated with the Thermogan measuring instrument had an accuracy of reading the temperature of $98.8 \%$ with a difference of $1.16 \%$.
\end{abstract}

Keywords-Chamber, Covid, Disinfectant, Portable .

\section{INTRODUCTION (HEADING 1)}

COVID-19 is an infectious disease caused by the Severe Acute Respiratory Syndrome Coronavirus 2 (SARS-CoV-2), which can spread through interactions from the nose or mouth that come out when a person infected with COVID-19 coughs or exhales. $\mathrm{mm}$ then falls on nearby objects and surfaces. People who touch these objects or surfaces and then touch their eyes, nose or mouth, can contract COVID-19.[1]

The government is trying to suppress the spread of the covid-19 virus, namely by urging the public to implement the New Normal health protocol, namely new adaptation-based behavior habits to cultivate clean and healthy living behavior [2], Then there is a tool called a disinfectant booth, how to use this tool by spraying or rubbing on various inanimate objects that may be exposed to the virus [3][4]. There is also the usual use of antiseptic among the community. For now, many have used disinfectant booths in several public places, in order to stop the current spread of the Covid-19 virus, disinfectant spraying is still done manually and requires officers to operate it, in an effort to prevent each area from carrying out body temperature tests and spraying disinfectants. to people entering the area. The normal body temperature of adults ranges from 36.5 to $37.5 \mathrm{C}$ [5]. However, the human body temperature can change throughout the day. Disinfectant spraying is still done manually and requires staff to operate it.
With these problems, a tool is needed so that a disinfectant liquid sprayer is needed that works automatically. This tool uses ultrasonic sensors as object detectors and Arduino Uno as controllers. The output uses a Relay module which is connected to a High Pressure Water Pump which sprays the disinfectant liquid through a mist sprayer.

\section{METHODS}

Tool design includes the design of the physical appearance that will be built as desired. This section consists of mechanical, electrical and software designs that are interconnected to carry out a step-by-step process according to the design.

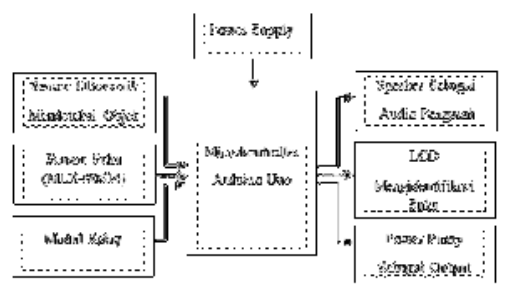

Fig.1 Block diagram of the designed system

The explanation of each system block diagram is as follows:

a. Power supply functions as a tool that is able to provide a supply of electric current to all components of the microcontroller.

b. Ultrasonic sensors detect the presence of objects.

c. The speaker plays an active role as a guide for each component designation.

d. The temperature sensor (MLX-90614) works to detect temperatures in the temperature range of $-70^{\circ} \mathrm{c}$ to $382^{\circ} \mathrm{C}$.

e. LCD (Liquid Crystal Display) helps as a calibration between the ultrasonic sensor and the temperature sensor in displaying the writing / temperature of the object.

f. The Relay Module works automatically after taking temperature measurements, then the Power Pump will directly work as an Output.

Software Design Stage The software design stage is carried out directly on the mechanical design and hardware tools that have been completed, in order to know firsthand the work of each component that will be controlled by the 
microcontroller. The following is a flow diagram of the tool system that will be made



Fig.2 Flowchart of the designed system

For software design in the disinfectant booth, it can monitor the level of human body temperature and the effectiveness of the working system of this tool. in this design the system is automatic in life, if the disinfectant booth is very efficient in working and has features when it supports it compared to having to work manually.

The design of the tool in the design of this smart waste monitoring tool uses a disinfectant booth made of PVC pipe which is arranged in such a way that makes the cubicle look portable and efficient, mechanically the tool can still function automatically as well. This system will work if there is an object that is captured by the ultrasonic sensor and the temperature sensor will automatically measure it manually. after the sensor has worked, the relay will automatically run the work system from the electronic pump below.

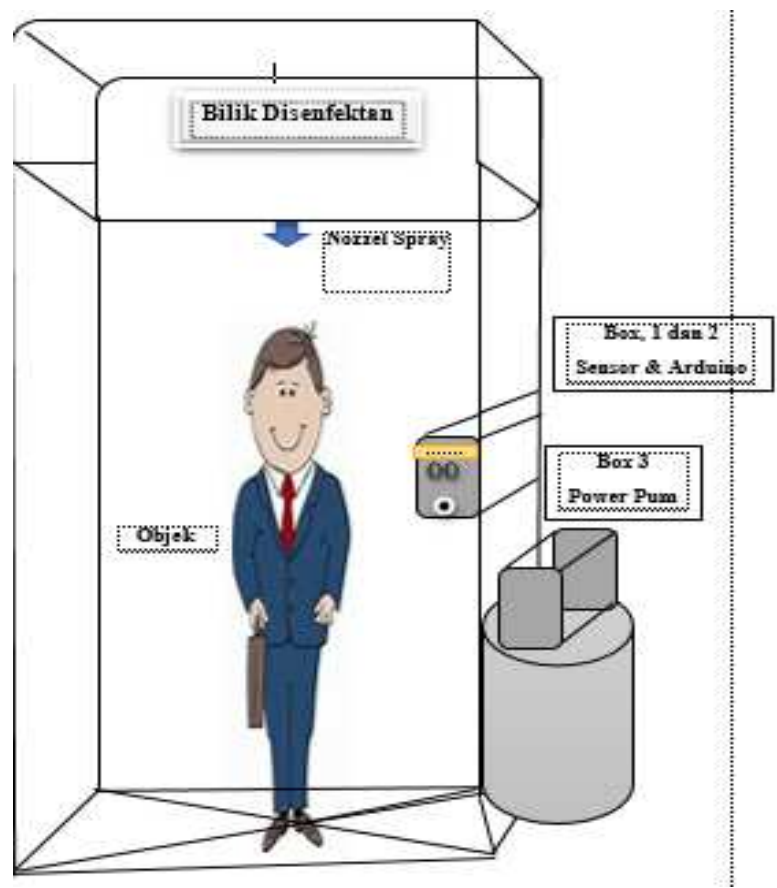

Fig.3 Disinfectant device design

\section{RESULTS AND DISCUSSION}

The collection and presentation of data is a very important part in making reports or research. Each type of report always uses data in presenting the facts or information contained in the report. Tool testing aims to determine whether this smart waste monitoring tool works efficiently.

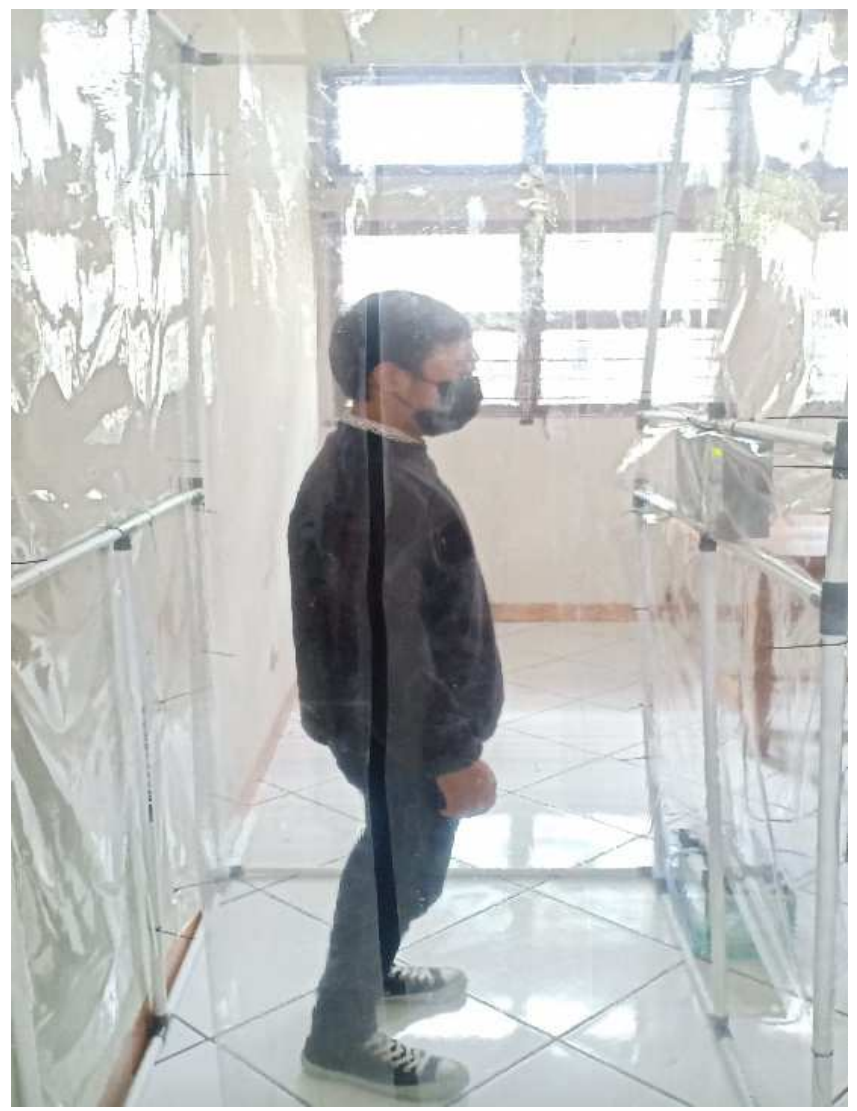

Fig. 4 Disinfectant device trial 
In the table below, look for tool errors in lab tests by taking data from automatic temperature measuring devices with conventional temperature measuring devices in stages by knowing the difference and error percentage.

Table I. Temperature measurement result with a distance of $1 \mathrm{~cm}$

\begin{tabular}{|c|c|c|c|c|c|}
\hline No & $\begin{array}{l}\text { Jarak } \\
(\mathrm{cm})\end{array}$ & $\begin{array}{c}\text { Suhu Badan } \\
\text { Pada Bilik } \\
\text { Disinfektan } \\
\left({ }^{\circ} \mathrm{C}\right)\end{array}$ & $\begin{array}{c}\text { Suhu Badan } \\
\text { Pada } \\
\text { Termogan } \\
\left({ }^{\circ} \mathrm{C}\right)\end{array}$ & $\begin{array}{l}\text { Selisih } \\
\left({ }^{\circ} \mathrm{C}\right)\end{array}$ & $\begin{array}{c}\text { Persentase Eror } \\
(\%)\end{array}$ \\
\hline 1. & \multirow{10}{*}{1} & 36,21 & 36,69 & 0,48 & 0,01 \\
\hline 2. & & 36,85 & 37,0 & 0,15 & 0,004 \\
\hline 3. & & 36,05 & 37,0 & 0,95 & 0,02 \\
\hline 4. & & 36,53 & 36,8 & 0,27 & 0,007 \\
\hline 5. & & 36,47 & 37,0 & 0,53 & 0,014 \\
\hline 6. & & 36,47 & 37,0 & 0,53 & 0,014 \\
\hline 7. & & 36,13 & 37,0 & 0,87 & 0,024 \\
\hline 8. & & 36,77 & 37,0 & 0,23 & 0,006 \\
\hline 9. & & 36,93 & 37,1 & 0,17 & 0,004 \\
\hline 10. & & 36,91 & 37,1 & 0,19 & 0,005 \\
\hline $\mathrm{R}$ & a-rata & 36,53 & 36,96 & 0,43 & 0,0108 \\
\hline
\end{tabular}

Table II. Temperature measurement result with a distance of $2 \mathrm{~cm}$

\begin{tabular}{|c|c|c|c|c|c|}
\hline No & $\begin{array}{l}\text { Jarak } \\
(\mathrm{cm})\end{array}$ & $\begin{array}{c}\text { Suhu Badan } \\
\text { Pada Bilik } \\
\text { Disinfektan } \\
\left({ }^{\circ} \mathrm{C}\right)\end{array}$ & $\begin{array}{c}\text { Suhu Badan } \\
\text { Pada Termogan } \\
\left({ }^{\circ} \mathrm{C}\right)\end{array}$ & $\begin{array}{l}\text { Selis } \\
\text { ih } \\
\left({ }^{\circ} \mathrm{C}\right)\end{array}$ & $\begin{array}{c}\text { Persentase } \\
\text { Eror } \\
(\%)\end{array}$ \\
\hline 1. & \multirow{10}{*}{2} & 36,77 & 37,0 & 0,23 & 0,006 \\
\hline 2. & & 36,87 & 37,1 & 0,23 & 0,006 \\
\hline 3. & & 36,61 & 37,0 & 0,39 & 0,010 \\
\hline 4. & & 36,49 & 37,0 & 0,51 & 0,013 \\
\hline 5. & & 35,99 & 37,0 & 1,01 & 0,028 \\
\hline 6. & & 36,53 & 37,1 & 0,57 & 0,015 \\
\hline 7. & & 36,65 & 37,1 & 0,45 & 0,012 \\
\hline 8. & & 36,79 & 37,1 & 0,31 & 0,008 \\
\hline 9. & & 36,69 & 37,1 & 0,41 & 0,011 \\
\hline 10. & & 36,47 & 37,0 & 0,53 & 0,014 \\
\hline \multicolumn{2}{|c|}{ Rata-rata } & 36,58 & 37,05 & 0,46 & 0,0123 \\
\hline
\end{tabular}

Table III. Temperature measurement result with a distance of $3 \mathrm{~cm}$

\begin{tabular}{|c|c|c|c|c|c|}
\hline No & $\begin{array}{l}\text { Jarak } \\
(\mathrm{cm})\end{array}$ & $\begin{array}{c}\text { Suhu Badan } \\
\text { Pada Bilik } \\
\text { Disinfektan } \\
\left({ }^{\circ} \mathrm{C}\right)\end{array}$ & $\begin{array}{c}\text { Suhu Badan } \\
\text { Pada } \\
\text { Termogan } \\
\text { ('C) }\end{array}$ & $\begin{array}{l}\text { Selisih } \\
\left({ }^{\circ} \mathrm{C}\right)\end{array}$ & $\begin{array}{c}\text { Persentase } \\
\text { Eror } \\
(\%)\end{array}$ \\
\hline 1. & \multirow{10}{*}{3} & 35,99 & 37,0 & 1,01 & 2,10 \\
\hline 2. & & 36,11 & 36,9 & 0,79 & 5,26 \\
\hline 3. & & 35,99 & 37,0 & 1,01 & 1,06 \\
\hline 4. & & 35,51 & 36,9 & 1,39 & 5,14 \\
\hline 5. & & 35,37 & 37,0 & 1,63 & 3,07 \\
\hline 6. & & 35,65 & 37,0 & 1,35 & 2,54 \\
\hline 7. & & 35,33 & 37,0 & 1,67 & 1,91 \\
\hline 8. & & 35,31 & 37,0 & 1,69 & 7,34 \\
\hline 9. & & 35,47 & 36,9 & 1,43 & 8,41 \\
\hline 10. & & 35,05 & 36,9 & 1,85 & 9,73 \\
\hline \multicolumn{2}{|c|}{ Rata-rata } & 35,57 & 36,96 & 1,38 & 4,656 \\
\hline
\end{tabular}

In the table above, the value of measuring body temperature is 10 times the experiment was carried out with 3 different distance variants, between $1 \mathrm{~cm}$ to $3 \mathrm{~cm}$ and compared with the results of measurements using conventional measuring instruments (Thermo gun), the highest average value is found in distance measurements. 3 $\mathrm{cm}$ with a value of $1.38 \mathrm{C}$. While the lowest difference value is the result of $1 \mathrm{~cm}$ distance measurement with the average value obtained is $0.43 \mathrm{C}$

In testing the ultrasonic sensor, the test was carried out by making comparisons and conclusions by controlling at each predetermined distance with the distance listed in the disinfectant booth. This measurement data is in accordance with the following table:

Table IV. Accuracy of reding on the ultrasonic sensor system

\begin{tabular}{|c|c|c|c|c}
\hline No & $\begin{array}{c}\text { Jarak } \\
\text { Pada } \\
(\mathrm{Cm})\end{array}$ & $\begin{array}{c}\text { Jarak benda yang } \\
\text { terdeteksi pada } \\
\text { Bilik Disinfektan } \\
(\mathrm{cm})\end{array}$ & $\begin{array}{c}\text { Selisih } \\
(\%)\end{array}$ & $\begin{array}{c}\text { Persentase } \\
\text { Eror }(\%)\end{array}$ \\
\hline 1. & 10 & 9,8 & 0,002 & 0,0002 \\
\hline 2. & 20 & 20,1 & 0,003 & 0,00015 \\
\hline 3. & 30 & 29,4 & 0,60 & 0,02 \\
\hline 4. & 40 & 39,2 & 0,80 & 0,02 \\
\hline 5. & 50 & 48,5 & 1,50 & 0,03 \\
\hline 6. & 60 & 59,2 & 1,40 & 0,14 \\
\hline 7. & 70 & 71,1 & 1,10 & 0,02 \\
\hline 8. & 80 & 83,4 & 3,40 & 0,04 \\
\hline 9. & 90 & 88,5 & 1,50 & 0,02 \\
\hline 10. & 100 & 98,5 & 1,70 & 0,02 \\
\hline
\end{tabular}

In this test, the author analyzes whether the reader system that is made is running well or not and what are the shortcomings of the designed tool. The following are some of the data observed by the author in some of his experiments as follows:

Table V. Observation the instrument system in the disinfectant booth

\begin{tabular}{|c|c|c|c|c|}
\hline No & Percobaan & Berfungsi & Tidak & Keterangan \\
\hline 1 & Percobaan 1 & Baik & - & \\
\hline 2 & Percobaan 2 & Baik & - & \\
\hline 3 & Percobaan 3 & Baik & - & \\
\hline 4 & Percobaan 4 & Baik & - & \\
\hline 5 & Percobaan 5 & Baik & - & \\
\hline 6 & Percobaan 6 & Baik & - & \\
\hline 7 & Percobaan 7 & - & tidak & $\begin{array}{l}\text { Sistem tidak terbaca di } \\
\text { karenakan pembacaan } \\
\text { terlalu cepat. }\end{array}$ \\
\hline 8 & Percobaan 8 & Baik & - & \\
\hline 9 & Percobaan 9 & Baik & - & \\
\hline 10 & Percobaan 10 & Baik & - & \\
\hline & Total & 9 & 1 & $\frac{9}{10} ? 100 \%=90 \%$ \\
\hline
\end{tabular}

From the data in the table above, namely testing the accuracy of temperature readings, data can be obtained, namely the occurrence of a temperature equation at a distance of $1 \mathrm{~cm}$. This shows that if the palm of the hand is attached very close to the sensor, the accuracy value is higher and the error percentage is smaller. However, in the test table the accuracy of the readings is different because it is influenced by a considerable distance. The data obtained is that disputes occur at a distance of $3 \mathrm{~cm}$, namely the percentage error value reaches $9.73 \%$ at a distance of $3 \mathrm{~cm}$.

The percentage of sensor accuracy in temperature readings from the average number of temperature tests with a distance of $1 \mathrm{~cm}$

Temperature difference: $36.53-36.96=0.43 \%$ 
Percentage of temperature difference : $0.43 / 36.96 \times 100 \%=$ $1.16 \%$

Percentage of error accuracy : $36.53 / 36.96 \times 100 \%=98.8 \%$

Percentage of sensor accuracy in temperature readings from the average number of temperature tests with a distance of 3 $\mathrm{cm}$

Temperature difference: $35.57-36.96=1.39 \%$

Percentage of temperature difference : $1.39 / 36.96 \times 100 \%=$ $3.7 \%$

Percentage of error accuracy : $35.57 / 36.96 \times 100 \%=96.2 \%$

\section{CONCLUSION}

After conducting experiments to determine the accuracy of the sensors and system performance of the Arduino Uno in running the system, the desired results were obtained. The sensor detects the temperature in the disinfectant booth and the Arduino is able to run the program properly. Although there are still some that still need improvement.

According to the data that has been obtained when testing the system, namely the difference in temperature sensor readings at a distance calibrated with another temperature measuring instrument (Thermo gun), it is known that the MLX 90614 sensor has the same accuracy within $1 \mathrm{~cm}$, which is $98.8 \%$ with a difference of $1.16 \%$. and accuracy within 3 $\mathrm{cm}$ is $96.2 \%$ with a difference of $3.7 \%$.

\section{REFERENCES}

[1]. Alodokter. (2021) Covid-19. [Internet]. Available on the page http://www.alodokter.com/viruscorona (accessed June 30, 2021: 14:56).

[2]. Task Force for the Acceleration of Handling Covid (2020). Adjustment of Learning Policies during the Covid-19 Pandemic. Retrieved from http://covid19.go.id

[3]. Wikipedia. (2021) Disinfectants. [Internet]. Available on the Disinfectant - Indonesian Wikipedia page, free encyclopedia (accessed 10 June 2021:11.30)

[4]. Kadir A. 2018. A Practical Guide to Learning Microcontroller Applications and Programming Using Arduino Uno. Yogyakarta: ANDI

[5]. N. P. Y. N, J. Pebralia, and Y. Citra (2015). "Study on the Application of the MLX 90614 Sensor as a NonContact Measurement of High Body Temperature Based on Arduino and Labview," vol. 2015, no Snips, p.90.

[6] Sujiwa, A., \& Ubaydillah, M. (2021). Arduino Based Temperature And Humidity Monitoring Control System for Day Old Chicken (DOC) Cage. BEST: Journal of Applied Electrical, Science, \& Technology, 3(1), 22-25. 